\title{
Communication of Environmental Awareness: The Paserong for Sustainable Development of The Orang Bajo
}

\author{
Mukti Ali', Rasimin Rasimin², Ilyas Ilyas ${ }^{3}$, Zaenal Muttaqin ${ }^{4}$ \\ \{muktiali@iainsalatiga.ac.id ${ }^{1}$, rasimin@iainsalatiga.ac.id ${ }^{2}$, ilyas.pnf@mail.unnes.ic.id ${ }^{3}$, \\ zmuttaqin@uinjkt.ac.id $\left.{ }^{4}\right\}$ \\ 1,2 Institut Agama Islam Negeri Salatiga, Salatiga Indonesia \\ ${ }^{3}$ Universitas Negeri Semarang, Indonesia \\ ${ }^{4}$ Universitas Islam Negeri Syarif Hidayatullah Jakarta, Tangerang, Indonesia
}

\begin{abstract}
Abstact. This research was used ethnographic methods on Indonesian sub-culture communities, Orang Bajo. A community group around the coast of Saponda and Kendari, Southeast Sulawesi. The phenomena of the Orang Bajo was awareness to understand ecosystem sustainability as a manifestation of the reason that values were passed down through old generations, and should not be lost from the lives of his grand children. Although basically the culture of their parents did not conflict and coherently with the reality of the teachings they believed in. Intend to reconstruct the concept of fishing with the Paserong system which had a good impact on the development of environmental awareness behavior of a society, so as not to give birth to ecosystem damage without reducing the value of the economic welfare of the community. A very eminent tradition, as well as the identity of the Orang Bajo people without having to destroy marine habitats and ecosystems, for example the Paserong system. The Paserong system was a fishing system carried out by few fishermen, especially Bajo or Sama tribes. And even now the fishing system was still being used and preserved. The Paserong system was a location prepared by Bajo fishermen made of wide nets such as cages or garden fences made of nets tied to bamboo stakes on the sea floor. Usually the Paserong system was carried out by one group consisting of several people in making, installing, and distributing results.
\end{abstract}

Keywords: Orang Bajo, Biota Ecosystem, Paserong and Nganda, Environmental Awareness, Sustainable Development.

\section{Introduction}

The Orang Bajo saw the sea as a living land, a place for breeding, as well as an area to make a livelihood, so that the intensity of the closeness of the Orang Bajo has awareness to care for the environment in order to keep sustainability of life. Muhammad Obie at. al. [1], looking at Orang Bajo concern and high environmental awareness, that they own the coastal and marine resources in their surroundings. They keep and protect the resources and the ecosystem is well protected and preserved. Yohanes Kristiawan Artanto [2], identifies the naming, term, and mention of Bajo, Bajo tribe, or Orang Bajo, Bajo People better known in the eastern part of Indonesia, namely a local unit or community group that can be found in the islands and sea of Sulawesi, East Kalimantan, East Nusa Tenggara, West Nusa Tenggara, and 
North Maluku, while in the western part of Indonesia, in Riau sea. According to Indrawarsih and Antariksa [3]. Orang Bajo community groups who are shifting and spreading lives in Indonesian sea, including the Riau Islands, Bone Bay, Selayar Island, Kendari Beach, Muna Island, Buton Island, Wakatobi Islands, Peling Island, Banggai Islands, Manado, Island Nain, Tomini Bay, Togian and Torosiaje Islands, Bontang and Pulau Laut, Bacan Island, western Flores Island, eastern Sumbawa Island. Outside of Indonesia they are found in Sabah sea of Malaysia, Thailand, Myanmar, and on the Sulu coast of the Philippines. Suryanegara, Ellen, Suprajaka, Irmadi Nahib [4], concluded that in some literature even Orang Bajo were identified with various nicknames including boat people or sea gypsy.

The name Bajo or Bajau is the name given by outsiders to them, just like Orang Laut [5]. While the name Bajo or Bajau itself is only applied to groups of people who live in eastern Indonesia, such as Sulawesi, Maluku and Nusa Tenggara, while the community groups located in the Riau Islands are better known as the Orang Laut, Suku Laut, Orang Pesukuan, and Rakyat Laut. Indrawasih and Antariksa [6], stated that if their names were listed, they would increase in length if they mentioned names used by foreign researchers in their writings, such as Sea Peoples, Sea Nomads, Sea Gypsies, Boat Nomads, Nomadic Boat Peoples and so on. The Orang Bajo call them selves Orang Sama, Sammal, Sammah, which means fellow or my neighbor. Mukti Ali [7], describes that Orang Bajo who used to live in these houseboats did not have a fixed place, so it was not wrong when they were categorized as nomadic communities. Regarding the nomadic community, Orang Bajo can be reflected in the custom of Orang Bajo who moves from one place to another which is considered to have a lot of fish or just follow where the wind blows pushing the karoro, a boat screen made of pappas, the direction they aim.

For example, Iziq Eafifi Ismail et.al, [8], explains in his research results in Malaysia, there are approximately 494700 Orang Bajau in Sabah by 2014 and the number expected to grow. Sama-Bajau on the other hand divided into two major groups: Jomo Sama or Sama Darat and A'a Sama or Sama Dilaut. Settlement patterns are dictated by these two sub-groups and painted an image of land settlement for nomads and boat-dwelling people for Sama Dilaut. This is a some what vague and generalized settlement, there is another sub-group called SamaLipidor also known as littoral. The Sama is believed to have been originated from Tawi-Tawi island. Another term for the Bajau is Bajau Kubang which can be found in Semporna and is believed to have been the earliest settlers in the region, but this term is only popularly used on the east coast. Regardless, several sub-groups are linked together via vertical social mobility that is transferred through ages, influences and acculturation, a product of sedentary processes. In this case the term Sama-Bajau is used by the term Sama; a Malay word that is brought about the meaning of 'same' or 'identical'. It also has been used collectively by several scholars.

Regarding to the fulfillment of the necessity of life with a role in the family, I see that the man of Orang Bajo are still dominant in their roles and responsibilities. The role structure of domination is of course related to their reality as fishermen. Men who go out to sea, while women stay at home to provide of domestic household governance, to maintain and process what men obtained is. The fervent life of the Orang Bajo, the position of men are more needed for their role than women, because the activity in the sea requires stronger physical of a man. Most of them are traditional fishermen who are able to use the marine wealth to survive their families. Even though women play a role in fulfilling their economic needs, they are merely a small additional part of men's main income. For example, just working as a cutter of sariawan or seaweed on one of neighbors who is a collector, considering that besides fish fishermen as daily primary work, the sariawan and seaweed business is also a very profitable business for 
the Orang Bajo. There are also forms of creative business by opening warung or stalls that provide residents' needs, processing dried fish, sea cucumbers, or the other sectors. The Sariawan is a type of soft coral, which is one of the relatively new economic commodities sectors of Orang Bajo. The pieces of sariawan are used to materials craft. One of the famous handicrafts of sariawan is a craft for making beads, bracelets, vast flowers, photo frames, and so on.

I tried to explore the pattern of the Orang Bajo 's economic culture. The results of observations raised two things related to the economic life patterns of the Orang Bajo : First, Orang Bajo do not have an economic system to become a benchmark for most of their people. There are no patern previously made and used as a basic for creating uniformity to carry out social economic activities. Second, the cultural values in the ikiko. Mukti Ali [9], explain that ikiko is a hidden sensitivity culture of Orang Bajo; "A child says to his mother. If you leave me. It really blew me away. Don't take me back for you to dump again". If we reflect on this sentence, whoever, psychologically it will collapse in his psyche, so wrenching and at the same time giving away a fate. But this expression will be normal for the Orang Bajo, about facing uncertainty their future, and that story will always be remembered in life every day.

In my field research, when the economic conditions of the Orang Bajo at the prosperity level. Their average income per day can reach one hundred thousand rupiahs, for lower-class Bajo fishermen using limited and simple boats and equipment, the distance only the sea around closest. Different from the case, with those entered to the big-class Bajo fishermen category. With adequate equipment, a large-engine ship capable of shortening and speeding up the distance to areas with abundant fish availability, so that they can produce ten to twenty million rupiah in a single fishing trip in a period of three days to a week. But if I mention and ask about what and how to use the proceeds from the sale of the sea harvest. They usually answer 'I don't know.' Something was interrupted in managing the results of their catch. Investing or saving is a system that is difficult for them to do. Titiek Suliyati [10], formerly, Orang Bajo make a living at sea based on working groups, namely: (1) Lilibu is a small group of Bajo fishermen on small boats, fishing in areas not too far away within one to two days; (2) Papongka is a group of Bajo fishermen within one to two weeks in the deeper sea areas. (3) Sakai is a group of Bajo fishermen who sail to other islands for a longer time; (4) Lame is a group of Bajo fishermen who sail with large motorized boat and crew go to other countries for months.

\section{Result and Discussion}

\subsection{Nganda: The Logical Mistakes in Sustainability}

Since childhood, many of Orang Bajo boys have begun to be involved by their father to join in fishing at the sea. They are in charge of preparing pukak or trawlers, bubu, and other equipment. Pukak and bubu are simple technology fishing gear, a legacy from their ancestors. Medi Saputra [11], views that habituation activities are carried out to help foster maximum environmental awareness so that they are trained to actions that support environmental preservation. If you are trained in habituation activities, a relatively permanent and automatic behavior transformation is expected Aswandi [12]. Megawangi [13], states that one of the causes of one's inability to behave well; although cognitively knowing it, it is not trained to do moral actions. When their ancestors still lived on boats, no technological changes meant fishing. As explained by Muh Nur Sangadji [14], that Orang Bajo have various fishing techniques, including missi (fishing), ngarua (trawling), mana (archery using traditional tools), nyuluh, balobe or commonly known as ngobor. Although, the technology of catching fish can 
still be seen and used by a small part of Orang Bajo today. But the yield of their sea catches are not much, so that pukak and bubu are only a small part of the long history and wisdom of people who are almost extinct.

When in the crossing towards Saponda, a small island inhabited by Orang Bajo, I saw with my own eyes, the Bajo fishermen quickly throwing bottles which then exploded. Two other fishermen friends plunged from their small boat, katinting, without oxygen cylinders, without buoys, also not using swimming goggles, diving through the sea water to catch fish that died from loud explosions, floating around explosions. Large and small fish appear floating, not a few fish are still staggering, between life and death. One by one the large fish were caught and thrown into katinting. Every now and then they use (drafts) to facilitate catching the fish compared to their bare hands, because the motion of sea water continues to swing the fish that have died from the blast of bomb.

From the phenomena that occur above, to get bomb terminology in the life of the Bajo is very diverse, because there are also various types of assemblies, basic materials, material acquisition, and media models. Commonly the Orang Bajo called nganda. When I live with Orang Bajo, the phenomena and methods of catching up with bombs can be found in several terms in the field; explosives, dynamite, fertilizer, powder, or poisons. Otniel Pontoh [15], explained that currently the manufacture of fish bombs has undergone modifications, if in the past they used gunpowder from bullets, fishermen are now using materials such as bottles, urea fertilizers, kerosene, rubber slippers, matches, paper tin, paperboard, sand paper, plastic bags, threads and candles. Fish species that are often caught by bombs are fish that live around reef waters; Bobara fish, Goropa fish, Kembung fish, Pisangor banana fish, and Baronang fish. In addition to large fishes that died from bombs, small fish were also victims but were left to sink.

The views of still depends on the mercy of nature is the primordial identity of Orang Bajo. Using seafood for consumption and also sell it to meet family needs. However, dependence, utilization, and making the sea an excessive commodity without prioritizing values of environmentally awareness will adversely affect to the survival of Orang Bajo themselves later. Abdullah Karatas [16], reiterated that a harmonious relationship between human and nature can be reached through environmental ethics as people will be able to understand the real value of nature. Environmental ethics provides the link that re-establishes the paleolithic consciousness and awareness that has been linked to improve wellbeing. The philosophers have linked modernity to increase alienation from wild life as we increasingly live in cyberspace, hyper or virtual reality, online and indoors becoming 'natural aliens and cyborgs' subjected to Nature-Deficit-Disorder [17]. This human expansion has been accompanied by fundamental changes in the scale, intensity and character of relationships with the natural world [18]. The Earth is said to enter a new geological epoch, the Anthropocene [19], migrating from the Holocene, the interglacial era that has provided humanity, over the past 100 decades, with extraordinarily rich ecoystems that have sustained and enhanced development of modern societies [20].

On the experience of the Orang Bajo, the sea is everything, because they will continue to depend on the sea as their only source of livelihood. The Bajo more attention to the marine environment and regard the sea as their source of income and source of life, so Orang Bajo have to protect and preserve marine life. Otniel Pontoh [21], in his research saw, that there was an opinion from outside which stated that the Orang Bajo took fish in the sea by illegal means, such as bombs and poisoning, thus damaging what's inside. After further investigation, it turned out that the people who carried out the destruction were outsiders, and the Orang Bajo only become scapegoats. The Orang Bajo, who have closeness emotional and historical 
with the sea have no reason to destroy the sea, because they believe that if they destroy the sea, it is like destroying their own lives. Syahriana Syam, et.al. [22], explained that, the element of the natural environment is the most important element and can affect other elements, where the natural environment has territorial boundaries in nature. So that characteristics can be obtained from the physical condition of the environment, culture and social life related to the history of society through space and time.

When the government and non-government organizations intervenes to prohibiting using nganda or bombs for fishing through methods of socialization and awareness on all elements of society. Orang Bajo realize that is truly destructive and acknowledges the impact on the existence of a damaged sea, and causes damage to marine habitats due to the torn apart of fish gathering places. But the fundamental problem is how the solution to leave the bad and harmful habits. The conscious cultural aspect inherent in Orang Bajo, the sea is their main home and must be preserved. There are several studies about the Orang Bajo as protectors of marine ecosystems. Research of Julian Clifton and Chris Majors [23], shown that indigenous and ethnic minorities are often perceived and regarded as friends of conservation efforts by the government, so that from the openness of the Bajo people can help efforts to conserve the oceans which are increasingly damaged by irresponsible human activities.

\subsection{Paserong; The Environmental Awareness for Sustainable Development}

After sunset I chat with Katua Kampoh, head or elder in the Orang Bajo community. Sitting in the living room, chatting flowed and from there I got a very valuable explanation, about the paserong, a very simple system or method, by producing abundant fish catches, without destroying nature, the environment and marine life being maintained, which later bequeathed to future generations. Paserong is a fishing system carried out by several fishermen, especially Orang Bajo. This fishing system is basically inherited from generation to generation and still used and preserved. Paserong also means tools made of wide webs like cages, can be interpreted as fishing locations determined, selected and prepared by Bajo fishermen. The description, paserong is a net fence tied to bamboo as a peg on the seabed with a certain location that is considered a traffic lane of clustered fish, Cakalang or skipjack fish. Fishing through this paserong system can last a long time, half a year, one year, even up to two years, depending on the strength of the net fence with several harvests.

Interestingly, besides the paserong prosper for income and is safe for environmental sustainability, but can also be rented to other people in accordance with the price agreement and how long it will be rented. Even in addition to contracted paserong can also be traded. One of the Orang Bajo's fishermen confirmed his experience that in the past, the passages were filled with cakalang or skipjack fish which in total yielded about five times the boat load at a price approximate thirty million to fifty million rupiah and not including fish distributed free of charge for 'sayur' or vegetable residents. The term 'sayur' or vegetables in the Orang Bajo communities is asking for or taking fish from people not for sale, but for selfconsumption. So, if we see that there are people who are fishing or there are people who are buying and selling fish in large quantities.

The Paserong also can mean as a local value that is very concerned about environmental awareness and preservation in the Orang Bajo culture. There are similarities in reading the problems of environmental concern, especially the marine environment. Some research findings have found that marine species and habitats are critical elements of the world biodiversity and are essential for human well-being. Yet, humans have caused major impacts on biodiversity, through overharvesting, habitat degradation, introducing invasive species, 
pollution and now, through induced climate change. Marine biodiversity is particularly vulnerable. Marine production and still enhancing while still using marine resources; Butler and Campbell [24], Turner and Clifton [25], Berkes, (2012); [26] Lepofsky and Caldwell [27]. Comberti et al., [28]. Thornton and Deur [29], Mathews and Turner [30]. According to Zsoka et.al. [31], that environmental knowledge is to know and aware of environmental problems and their resolutions. In general, the most important dimensions of each individual's environmental awareness are environmental knowledge, values, willingness to act and actual behavior influenced by several factors including elements of intention and situation.

Britha Mikkelsen [32], gives a strategy, of course this is one of the advances in technology and information effects, that will shift the presumption that Orang Bajo are personal who uphold of behavioris, a unity of humanity and naturality, a life that is in harmony with nature. The solutions are needed to through developing shared awareness in preserving the environment through collective power. This form of awareness refers to the request of group members that the community does not seem to understand protecting the environment.

Orang Bajo, besides having a strong basic view of wide sea expanse, a common property, so the term is not known as limitation, and individual ownership. It also has a lot of wisdoms that underlies the preservation of nature and the environment, very respects to life between awareness and wisdom in exploiting nature for its survival. One of the few simple expressions of the Orang Bajo wisdom about the value of their daily lives 'toho busei, toho karanja'. More or less the meaning is; dry paddle, dry basket. Paddles are movers of boats that are based on the strength of the hand, while the basket is the place to put the fish they catch. If they do not row to go fishing and catch fish, the basket will always be empty, and there will be no result for survival. So that philosophically meaning that expression strengthens the spirit to maintain survival. In addition to the above phrases, there is also a figure of speech that is also used as part of the continuity of their lives which says 'lamong nggai nginta dayah nggai nginta papuna'. If the fish does not eat bait, then the master will not eat the feed. This is the identity of the Bajo people, who cannot be separated from the sea, depending on the results of fishing. Repeated on how they lived their lives above the sea.

\section{Conclution and consideration}

The traditional fishing systems can be a problem for fishers. Survival factor is a very rational reason for them. With little fishing results, and requests to support large families, more promising methods are needed. Bombs can be considered as a solution. This is an alarming behavior, so efforts need to be made to promote polite behavior towards nature and want to play an active role as an agent who invites fishermen to be friendly in finding fish in the sea, so that marine ecosystems are sustainable and not damaged.

Bajo people need full awareness that maintenance and improvement of the environment. the marine environment and wealth contained within it, will affect various aspects of social security; culture, education, and economy, especially in the survival of nature itself. People must have a big impact on survival in the future. Without realizing it, there is still a practice of utilizing environmental resources through exploitative behavior that is considered to disturb the preservation of natural resources, especially the sea and the biota contained in it.

\section{References}

[1] Obie, Muhammad, Soetarto E., Sumarti T., Saharuddin: The Tragedy of Coastal And Marine Resources and Socio-Economic Vulnerability of Bajo Tribe in Tomini Bay, 
Indonesia. International Journal of Research in Social Sciences. Vol. 4, No. 6, 2014, Pp. 53-60, 2014.

[2] Artanto, Yohanes Kristiawan: Bapongka, Sistem Budaya Suku Bajo Dalam Menjaga Kelestarian Sumber Daya Pesisir. Sabda Journal of Cultural Analysis. Vol. 12, No.1, pp. 52-69, 2017.

[3] Indrawasih, Ratna, G.P. Antariksa: Budaya Bajau: Pemanfaatan dan Pelestarian Lingkungan. Jurnal Masyarakat dan Budaya. Vol. 5 No.2, pp.59-75, 2003.

[4] Suryanegara,Ellen, Suprajaka, Irmadi Nahib: Majalah Globe. Vol. 17, No.1, pp. 67-78, 2015.

[5] Lapian, Adrian B.: Orang Laut, Bajak Laut, Raja Laut: Sejarah Kawasan Laut Sulawesi pada Abad XIX. Komunitas Bambu, Jakarta. pp. 80, 2009.

[6] Indrawasih, Ratna, G.P. Antariksa: Budaya Bajau: Pemanfaatan dan Pelestarian Lingkungan. Jurnal Masyarakat dan Budaya. Vol. 5 No. 2, pp. 59-75, 2003.

[7] Ali, Mukti: Mengkomunikasikan Pendidikan dan Melestarikan Kearifan Lokal Orang Bajo. Inferensi Jurnal Penelitian Sosial Keagamaan. Vol. 11, No. 1, pp. 187-206, 2017.

[8] Ismail, Iziq Eafifi, Abdullah Sani Ahmad, Ismail Ibrahim: Influences of Regional SamaBajau Coastal Dwellings: Social Perspectives Through Identity Molding, International Journal of Culture and History. Vol. 1, No. 2, pp. 115-121, 2015.

[9] Ali, Mukti: Suatu Etnografi Suku Bajo. STAIN Salatiga Press, Salatiga, pp. 96, 2010.

[10] Suliyati, Titiek: Social Change of Bajo Tribe Society in Karimunjawa: From Sea Tribe to Land Tribe. Journal of Maritime Studies and National Integration. Vol. 1, No. 2, pp. 128138, 2017.

[11] Saputra, Meidi: Pembinaan Kesadaran Lingkungan Melalui Habituasi Berbasis Media Sosial Guna Menumbuhkan Kebajikan Moral Terhadap Pelestarian Lingkungan. Jurnal Moral Kemasyarakatan. Vol. 2, No. 1, pp. 14-29, 2017.

[12] Aswandi: Membangun Bangsa Melalui Pendidikan Berbasis Karakter. Jurnal Pendidikan Karakter Publikasi Ilmiah Pendidikan Umum dan Nilai. Vol. 2. No. 2, 2010.

[13] Megawangi, Ratna: Pendidikan Karakter: Solusi yang Tepat Membangun Bangsa. BP Migas, Jakarta, 2004.

[14] Sangadji, Muh Nur, Sumardjo, Pang S Asngari, sunarmo Haji Soewito: Strategi Penyuluhan di Kawasan Konservasi (Kasus Taman Nasional Kepulauan Togean). Jurnal Penyuluhan. Vol. 7, No. 2, pp 27-37, 2011.

[15] Pontoh, Otniel: Penangkapan Ikan Dengan Bom Di Daerah Terumbu Karang Desa Arakan dan Wawontulap. Jurnal Perikanan dan Kelautan Tropis. Vol. 7 No. 1, pp. 57-58, 2011.

[16] Karatas, Abdullah: Environmental Ethics Education as a Tool for the Prevention of Environmental Problems in the Community. European Journal of Sustainable Development. Vol. 3, pp. 263-268, 2014.

[17] Boyer, Anne-Lise , Emeline Comby, Silvia Flaminio, et al.:The Social Dimensions of A River's Environmental Quality Assessment. Ambio Journal of The Human Environment. Vol. 48, pp. 409-422, 2019.

[18] Steffen, Will, Paul J. Crutzen and John R. Mc Neill: The Anthropocene: Are Humans Now Overwhelming the Great Forces of Nature?. Ambio Journal of the Human Environment. Vol. 36, pp. 614-621, 2007.

[19] Zalasiewicz, Jan, Mark Williams, Will Steffen, Paul Crutzen: The New World of The Anthropocene. Journal of Environmental Science and Technology. Vol. 44, pp. 22282231, 2010.

[20] Folke, Carl, Asa Jansson, Johan Rockstrom, et al.: Reconnecting to the Biosphere. 
Ambio Journal of the Human Environment.Vol. 40, pp.719-738, 2011.

[21] Pontoh, Otniel: Penangkapan Ikan Dengan Bom Di Daerah Terumbu Karang Desa Arakan dan Wawontulap. Jurnal Perikanan Dan Kelautan Tropis. Vol. 7 No.1, pp. 57-58, 2011.

[22] Syam, Syahriana, Ananto Yudono, Ria Wikantari, Afifah Harisah: EduARCHsia 2017. SHS Web of Conferences 41, 04006. 1-4, 2018.

[23] Clifton, Julian, Chris Majors: Culture, Conservation, and Conflict: Perspectives on Marine Protection Among the Bajau of Southeast Asia. Society \& Natural Resources an International Journal. Vol. 2, pp. 716-725, 2012.

[24] Butler, Virginia L., Sarah K. Campbell: Resource Intensification and Resource Depression in the Pacific Northwest of North America: A Zooarchaeological Review. Journal of World Prehistory. Vol. 18, No. 4, pp. 327-405, 2004.

[25] Turner. Nacy J., Helen Clifton: The Forest and the Seaweed': Gitga' at Seaweed, Traditional Ecological Knowledge and Community Survival. In: Menzies, C.R. (Ed.), Traditional Ecological Knowledge and Natural Resource Management. University of Nebraska Press, Lincoln, pp. 65-86, 2006.

[26] Berkes, Fikret: Sacred Ecology: Traditional Ecological Knowledge and Resource Management, third ed. Taylor and Francis, Philadelphia, PA, 2012.

[27] Lepofsky, Dana, Megan Caldwell.. Indigenous Marine Resource Management on the Northwest Coast ff North America. Ecological Processes 2, 12, 2013.

[28] Comberti, Claudia, Thomas F. Thornton, V. Wyllie de Echeverria, Trista Patterson: Ecosystem Services or Services to Ecosystems? Valuing Cultivation and Reciprocal Relationships Between Humans and Ecosystems. Global Environmental Change. Vol. 34, pp. 247-262, 2015.

[29] Thornton, Thomas F., Douglas Deur: Introduction to the Special Section on Marine Cultivation among Indigenous Peoples of the Northwest Coast. Human Ecology, Vol. 43, No. 2, pp. 187, 2015.

[30] Mathews, Darcy L., Nancy J. Turner: Ocean Cultures: Northwest Coast Ecosystems and Indigenous Management Systems In book Conservation for the Anthropocene Ocean: Interdisciplinary Science in Support of Nature and People. Academic Press, editor P. S. Levin and M. R. Poe, pp. 169-199, 2017.

[31] Zsoka, Agnes, Zsuzsanna Marjaine Szerenyi, Anna Szechy, Tamas Kocsis: Greening Due to Environmental Education? Environmental Knowledge, Attitudes, Consumer Behavior and Everyday Pro-Environmental Activities of Hungarian High School and University Students. Journal of Cleaner Production. Vol. 48, pp. 125-138, 2013.

[32] Mikkelsen, Britha: Methods for Development Work and Research: A Guide for Practitioners. Sage, London, pp. 63, 2005. 